日作紀（Jpn. J. Crop Sci.） $76 （ 2 ） ： 339-341 （ 2007 ）$

\title{
連載ミニレビュー
}

\section{作物の形態研究法：マクロからミクロまで エネルギー分散型 EDX 分析}

\author{
和田富吉 \\ (名古屋大学生命農学研究科)
}

$\mathrm{X}$ 線微小部分析電子顕微鏡で使用するエネルギー分散型分析法（EDX 分析法）は, 数ミクロン以下に絞り込んだ電 子線を，透過型あるいは走査型電子顕微鏡内の超薄切片や組織表面の微小部に照射し，発生する $\mathrm{K}$ 線， $\mathrm{L}$ 線， $\mathrm{M}$ 線な ぞの特性 X 線から, 測定部位に存在する無機構成元素を判定する，点分析法，線分析法，面分析法などがある．水平・ Russ（1978），Morgan（1985），合志・佐藤（1989）などの図書に，その操作法が記述されている．本稿では，透過型 電子顕微鏡で含リン顆粒すなわちフィチン顆粒を点分析した方法などを述べる.

\section{1. 透過型および走査型電子顕微鏡と EDX 分析}

EDX 分析装置には，透過型電子顕微鏡用と走査型電子 顕微鏡用とがある，走査型電子顕微鏡では，加速電圧が 15 $\mathrm{KeV}$ などと比較的低く，走査モードで観察しながら，イネ 細胞に集積された珪素の検出などに用いられている。透過 型電子顕微鏡では, $80 \mathrm{KeV}$ の加速電圧で微量の無機成分 などを確実に識別する。ここでは， $\mathrm{Ca} ， \mathrm{Mn}, \mathrm{Fe}, \mathrm{Zn}$ など， 多くの元素が検出される。通常, 試料の $1 \mu \mathrm{m}^{3}$ 程度の体積 から放出される特性 X 線を分析し, 微小領域を非破壊的に 測定する。

点分析では各点に含まれる各種元素から, 固有エネルギー をもつ特性 X線を放出させ，その強度を捕らえて微小部分 に含まれる構成元素を検出する. 線分析では横に試料面を走 査し，走査線に沿った特定元素の相対的な濃度比を測定す る. 面分析では, 電子線を $\mathrm{XY}$ 軸二次元に走査し, 特性 $\mathrm{X}$ 線のエネルギー値から元素の組織内分布像を記録する.

構成元素の定性分析や相対的定量分析は可能であるが, 生物細胞の厳密な定量分析は難しい。電子銃から発射され た電子線は，試料に到達するまでに空気分子と衝突し散乱 する。 その結果，分析領域の周辺からも X 線が発生する. 電子線が試料表面に照射されると，X線が励起され，さら に吸収・励起を繰り返しながら広がる。生物試料の場合は 数 $\mu \mathrm{m}$ まで広がる. 透過型電子顕微鏡の場合は試料が超薄 切片であるため, X 線の広がりは抑えられ微小領域の分析 が可能である，但し，正確な定量值を得るのは困難で通常 は，バックグラウンドの X 線強度に対する注目元素の X 線強度の比率を用いる。

\section{EDX 分析の事例}

Buttrose（1978）は，エンバクおよびモクマオウ類 （Casuarinaceae）の種子超薄切片を用いて，フィチン顆粒
を点分析した．表示モニターの横軸となる特性 X 線のエネ ルギー分散位置に， $\mathrm{Mg} ， \mathrm{P}, \mathrm{K}$ 抢よび $\mathrm{Ca}$ が比較的多く検 出された（第 1 図）。また微量元素として $\mathrm{Mn}$ および Fe が 表示された。この顆粒はフィチン酸，すなわちイノシトー ルヘキサリン酸の無機複合塩であることが示唆される。種 子に存在するフィチン顆粒は極めて硬く，超薄切片の作製 時に破損し，しばしば切片にナイフの傷跡（ナイフマーク） がつく.また長時間のX線照射で試料に穴があくことから， 対象顆粒がグロボイド顆粒であると推定される。

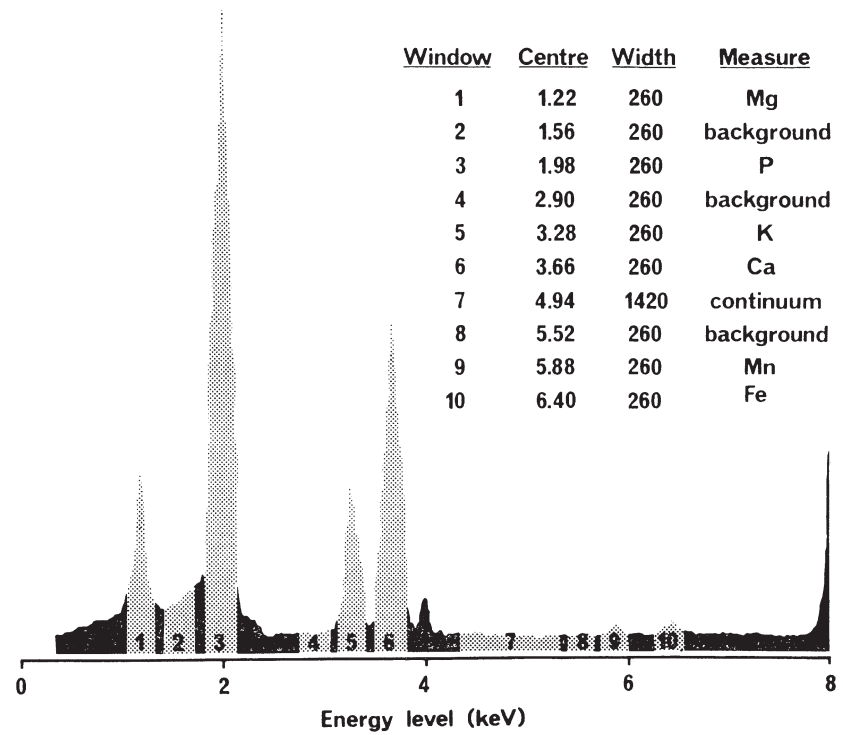

第 1 図 EDX ヒストグラム.横軸は X 線のエネルギー值，縦 軸はX 線量.

ハッチ部分は window 幅であり $\mathrm{eV}$ 表示, window 中心 は $\mathrm{keV}$ 表示である。 


\section{3. 種子内タンパク顆粒とフィチン顆粒}

植物種子には，デンプン，脂質，タンパク，無機質など が含まれており，それぞれ顆粒状構造として存在する。夕 ンパク顆粒については古くから研究が進められ，その機能 的役割が注目された。タンパク顆粒は植物の種類により特 徵的な構造を持つが，一般的にフィチン顆粒を封入体とし て含む。ムギ類やアブラナの種子のタンパク顆粒は，小型 のグロボイドを複数含む. ユーカリ類のタンパク顆粒では, シウ酸カルシウム結晶体を, カボチャ類ではクリスタロイ ドと呼ばれる結晶性タンパク体を含む。 タンパク顆粒の封 入体であるフィチン顆粒は古くからグロボイドと呼ばれ， そのなかに集積される無機成分が EDX 分析により詳しく 研究された (Lott 1980). 第 2 図に特徵的なタンパク顆粒と グロボイド顆粒を示した。植物種・組織部位・細胞の種類 により，種々の形態のタンパク顆粒が観察される.

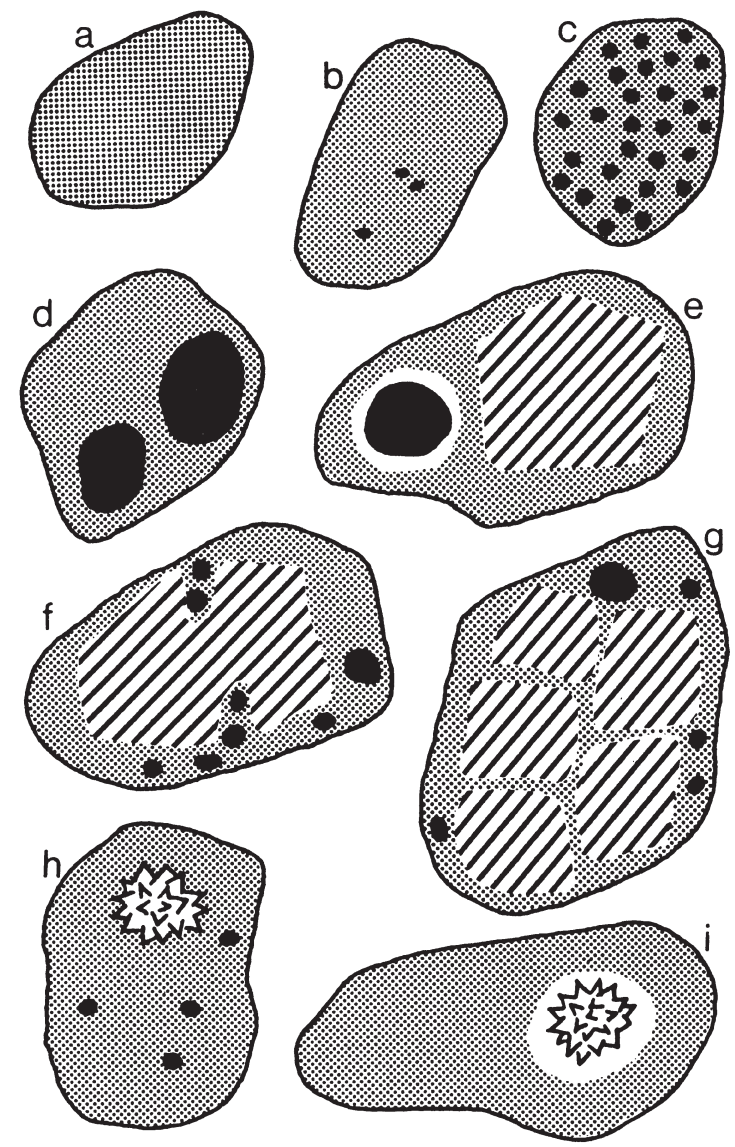

第 2 図乾燥種子の夕ンパク顆粒, 周囲が薄膜で囲まれ ている

$\mathrm{a}$ ：タンパク基質のみを含む, $\mathrm{b}$ から $\mathrm{d}$ ：タンパク 基質とグロボイド顆粒（黒点）を含む，eから g : タンパク基質とグロボイド顆粒（黒点）とタンパ ク結晶（白黒ストリップで示す）を含む， e ：ソフ トグロボイド (白の領域)がクロボイド顆粒を囲む, h：グロボイド顆粒と結晶質を含む，i：タンパク 基質から離れて結晶質がある。

\section{4. フィチン顆粒の EDX 分析}

1990 年代, 著者はカナダのマックマスター大学で J. N. A. Lott 教授と共同研究をおこなった. 日本電子社製の $100 \mathrm{CX}$ 透過型電子顕微鏡と Kevex 社製のエネルギー分散型 EDX 分析装置およびパソコン解析用システム装置が揃ってい た. イネ品種 Lemont (アメリカ合衆国産, ジャポニカ系統) の完熟種子を研究対象として用い, 点分析による EDX 解 析をおこなった。この研究は, 植物種子の発育や細胞機能 への無機成分の関与の把握を目的とした.

イネ胚を実体顕微鏡下安全剃刀の刃で切り出し, 無機成 分の保持に比較的よい結果が得られている高濃度のグル夕 ルアルデヒド固定液で固定し，塩素濃度の低い低粘度 Spurr 樹脂に包埋した. ドライカット法を用いて, 厚さ 0.25 $\mu \mathrm{m}$ から $0.5 \mu \mathrm{m}$ のやや厚い樹脂切片を作製し, 必要に応 じてカーボンコーテイング処理を施した。銅製グリッドに 試料をのせて分析すると $\mathrm{Cu}$ のピークが検出される場合が ある。

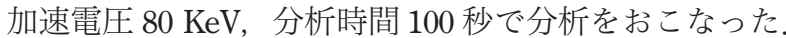
得られた点分析画像のスペクトラムは，バックグランドサ ブストラクション処理し，このデータをパソコンソフトの ミニタブ内に転送し，データごとの比較や組織部位別の特 徵整理をおこなった。ここでの点分析は，数百箇所の組織 部位別に約 1,000 回近くに達した。 イネ肧から検出された 構成無機成分は, Mg, P, K, Ca, Mn, Fe, Zn などで, 組織部位別に出現多様性が見られた（Wada and Lott 1997）. 完熟胚の糊粉層細胞内フィチン顆粒で, 高レベルの $\mathrm{Mg}, \mathrm{P}$, $\mathrm{K}, \mathrm{Ca}, \mathrm{Mn}$ が検出された (第 3 図). 分析結果から, 還元 土壌水田での種子形成と構成無機成分との関係が示唆され た。イネ種子の糊粉層細胞には, 巨大なフィチン顆粒が存 在する.

\section{5. 最近の研究など}

Lottとその共同研究者たちの最近の成果によれば，オー ストラリアのアルミニウム高含有乾燥土壤地帯に生育する バンクシア (Banksia : ヤマモガシ科) は, 種子内のフィチ ン顆粒に Ca が比較的高レベルに含まれている (Egerton-Warburton 5 1997)。 アラビドプシス類の種子の グロボイド内に $\mathrm{Mg}, \mathrm{P}, \mathrm{K}, \mathrm{Ca}, \mathrm{Fe}$ および $\mathrm{Zn}$ の存在が報 告された（Lott and West 2001）。裸子植物の種子では，高 鉄含有リン顆粒が葉緑体の中に検出された（Lott ら 2002）.

カボチャ類の花粉にフィチン顆粒が存在することを, Skilnyk と Lott（1992）が報告しており，それ以前に Jackson ら（1982）が花粉内にフィチン酸の存在を示し, 花粉発芽にイノシトールリン酸代謝の関与を指摘した。著 者らは, イネ種子形成過程における胚と糊粉層における フィチン顆粒の集積過程と, この部位に発現するフィチン 合成酵素の集積過程との関係を組織化学的観察で示した (Yoshida ら 1999). 今後の課題として, フィチン合成酵素 


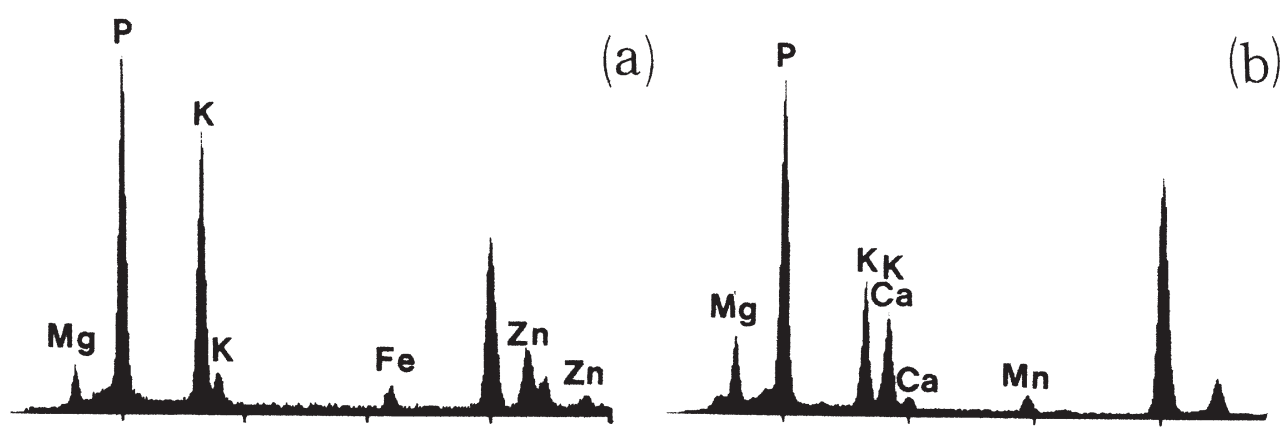

第 3 図乾燥イネ種子内のグロボイド顆粒のヒストグラム.

(a) : 幼根中心柱細胞のグロボイド顆粒, Fe や Zn などが検出された.

(b) : 背側糊粉層細胞のグロボイド顆粒, Ca や Mnなどが検出された.

の発現と耐塩性との関係や，低温抵抗性が示されているア イスプラントにおけるイノシトールリン酸代謝が注目され る。以上のように，フィチン顆粒が被子植物の種子や花粉 から裸子植物の葉緑体にまで広く存在することが分かりつ つある。また Lottら（2000）は，植物種子に関する諸研究 を総説にまとめている。

イネカルスでも再分化部位付近にフィチン顆粒が存在す

る (未発表)。フィチン顆粒は旺盛な生長が期待される組 織の近くに貯蔵される。生長・発育が開始される組織や, 活発な代謝が予見される細胞に集積される。種子の組織の ように長期大量に貯蔵され，発芽に際して消費される場合 と, 生長組織に短期少量貯蔵され，直ちに消費される一過 性の顆粒として存在する場合とがある。これは，貯蔵性種 子デンプン粒と一過性の組織デンプン粒の存在と対比され る.

著者らは，イネの葉身・葉鞘・節間部につき蛍光 $\mathrm{X}$ 線分 析と EDX 分析を実施し, 両分析法の比較をおこなった. その結果，蛍光 $\mathrm{X}$ 線では $\mathrm{Mn}, \mathrm{Fe}, \mathrm{Zn}$ が相対的に多く検出 され, EDXでは $\mathrm{Si}$ や P が多く検出された（和田 1985）. また収穫時の蛍光 $\mathrm{X}$ 線分析では，葉身内には $\mathrm{K}, \mathrm{Ca}, \mathrm{Mn}$ が多く，葉鞘と節間部には $\mathrm{K}$ が多く，節では $\mathrm{Mn}, \mathrm{Fe}, \mathrm{Zn}$ を多く検出した（和田・武岡 1986）。研究目的に対応した 分析法を使用する.

\section{引用文献}

Buttrose, M. S. 1978. Manganese and iron in globoid crystals of protein bodies from Avena and Casuarina. Aust. J. Plant Physiol .5 : 631-639.

Egerton-Warburton, L. M., M. West and J. N. A. Lott 1997. Conservative allocation of globoid-held mineral nutrients in Banksia grandis (Proteaceae) seeds. Can. J. Bot. : 75 : 1951-1956.

合志陽一・佐藤公隆 1989. エネルギー分散型 X 線分析, 学会出版セ ンター. 1-229.

Jackson, J. F., G. Jones and H. F. Linskens 1982. Phytic acid in pollen. Phytochemistry $21: 1255-1258$.
Lott, J. N. A. 1980. Protein bodies. In Tolbert N. E. ed., Biochemistry of Plants. Vol.1. Academic Press, New York. 589-623.

Lott, J. N. A., I. Ockenden, V. Raboy and G. D. Batten 2000. Phytic acid and phosphorus in crop seeds and fruits: a global estimate. Seed Sci. Res. $10: 11-33$.

Lott, J. N. A. and M. M. West 2001. Elements present in mineral nutrient reserves in dry Arabidopsis thaliana seeds of wild type and pho1, pho2, and $\operatorname{man} 1$ mutants. Can. J. Bot, 79 : 1292-1296.

Lott, J. N. A., J. C. Lin, K. A. Pennell, A. Lesage and M. M. West 2002. Iron-rich particles and globoids in embryos of seeds from phyla, Coniferophyta, Cycadophyta, Gnetophyta, and Ginkgophyta: characteristics of early seed plants. Can. J. Bot. 80 : 954-961.

水平敏知・J. C. Russ 1978. 分析電子顕微鏡, 日本メデイカルセンター 出版部 . 1-307.

Morgan, A. J. 1985. X-ray microanalysis in electron microscopy for biologists. Royal Microscopical Society Microscopy Handbook 05. Oxford Univ. Press, Oxford 1-79.

Skilnyk, H. R. and J. N. A. Lott 1992. Mineral analyses of storage reserves of Cucurbita maxima and Cucurbita andreana pollen. Can. J. Bot. 70 : 491-495.

和田富吉 1985. けい光 X 線分析法による植物体地上部の無機元素分 布に関する解析，日作東海支部研究梗概 100：7-10.

和田富吉・武岡洋治 1986. けい光 X 線分析法によるイネ地上部の無 機元素分布に関する解析，日作紀 55（別号 1）：252-253.

Wada, T. and J. N. A. Lott 1997. Light and electron microscopic and energy dispersive X-ray microanalysis studies of globoids in protein bodies of embryo tissues and the aleurone layer of rice (Oryza sativa L.) grains. Can. J. Bot. 75 : $1137-1147$.

Yoshida, K. T., T. Wada, H. Koyama, R. Mizobuchi-Fukuoka and S. Naito 1999. Temporal and spatial patterns of accumulation of the transcript of myo-inositol-1-phosphate syntase and phytin-containing particles during seed development in rice. Plant Physiology 119 : 65-72.

（和田富吉君は，この報文の原稿を残して 2006 年 5 月に亡 くなった，享年 56 。一部に手をいれ，また堀場製作所の 森田洋二氏のご意見を参考に脱稿しました。前田英三) 